\title{
PERANAN GURU BIMBINGAN KONSELING TERHADAP PEMBELAJARAN DARING SELAMA PANDEMI COVID-19
}

\author{
Imam Syafi'i ${ }^{1}$, Ika Qurrotul Afifah ${ }^{2}$ \\ Universitas Islam Negeri Sunan Ampel, \\ Imamsyafii.iwa@gmail.com \\ qurrotul1504@gmail.com
}

\begin{abstract}
The writing of this article contains an overview of the important role played by guidance and counseling teachers during covid-19. With the aim of finding a bright spot on the problems experienced by students during online learning. Given that some activities outside the home are limited, researchers have the opportunity to use the literature study method. Techniques for collecting data are sufficient by reviewing book references, journal articles and social media if necessary. From the data that has been collected, the next step is to analyze it so that conclusions can be easily drawn. Building communication and friendship between teachers and parents allows a counseling guidance teacher to have an idea of how to create an online learning atmosphere that is not boring. So that students will be enthusiastic and enthusiastic in participating in these activities.
\end{abstract}

Keywords: teacher role, guidance and counseling, online learning

\begin{abstract}
Abstrak
Penulisan artikel ini berisi tentang gambaran peran penting yang dilakukan oleh guru bimbingan dan konseling selama covid-19. Dengan tujuan untuk menemukan titik terang pada permasalahan yang di alami peserta didik Selama pembelajaran daring. Mengingat beberapa kegiatan diluar rumah di batasi maka peneliti berkesempatan menggunakan metode studi literatur. Teknik dalam mengumpulkan data cukup dengan mengkaji refrensi buku, jurnal artikel dan media sosial jika perlu. Dari data yang sudah terkumpul maka langkah selanjutnya dilakukanlah analisis sehingga dengan mudah dapat membuat kesimpulan. Hasil menunjukkan bahwa membangun komunikasi dan silaturahmi antara guru dengan orang tua memungkinkan seorang guru bimbingan konseling memilki gambaran
\end{abstract}


mengenai bagaimana menciptakan suasana pembelajaran online yang tidak membosankan. Sehingga peserta didik akan antusias dan semangat dalam mengikuti kegiatan tersebut.

Kata Kunci: peran guru, bimbingan dan konseling, pembelajaran online

\section{Pendahuluan}

Tepat sudah satu tahun lebih wabah covid-19 menyerang negara indonesia. Padahal awalnya Indonesia diprediksi akan "kebal" dengan wabah tersebut. Disebut bahwa kasus pertama kali penyebaran adalah terjadinya pertemuan antara perempuan dengan usia 31 tahun dengan warga negara asal jepang yang masuk ke wilayah Indonesia. Setelah ramai diperbincangkan oleh beberapa public dan mulai ramai jadi topik di media social akhirnya pemerintah mengambil alih dengan menetapkan beberapa kebijakan dan peringatan terhadap masyarakatnya. Mulai dari gerakan penyemprotan disinfektan di beberapa tempat aktivitas, memakai masker dan selalu mencucui tangan, lockdown, PSBB, dan kebijakan terbaru yang dikeluarkan yaitu PKKM, pembatasan keluar masuk transportasi, dan suntik vaksin. Segala aktivitas seperti pekerjaan sehari-hari hingga pendidikan pun terhambat pelaksanaannya dari keputusan yang dibuat oleh pemerintah. Akibat dari peristiwa tersebut banyak karyawan yang teperdaya PHK dalam beberapa lapangan pekerjaan seperti pabrik, kantor dan proyek, padahal selama ini pekerjaan itulah yang menjadi salah satu sumber penghasilan mereka.

Begitupun dengan lembaga pendidikan anak usia dini yang juga terpapar dampak dari covid-19, segala aktivitas pembelajaran yang dilakukan tatap muka kini beralih menjadi pembelajaran online atau daring dengan tagline Belajar Di 
Rumah atau yang biasa di sebut $B D R$. Kegiatan daring yang dilakukan lewat computer maupun gadget melalui platform seperti google classroom, zoom meet, WhatsApp, dan telegram yang terhubung dengan koneksi internet.

Pada awal diterapkannya pembelajaran online anak-anak antusias dan bersemangat, tetapi seiring dengan melambungnya pasien covid-19 semakin tidak mungkin jika pembelajaran dilakukan secara tatap muka. Jadi prosedur pembelajaran online tetap berlaku. Maka dari itu tidak sedikit orang tua merasa jika pembelajaran ini berjalan efektiv mereka merasa jika tanggung jawab dari guru beralih menjadi sebuah tanggung jawab penuh bagi orang tua. keterbatasan mengenai penggunaan tekonologi (gaptek) juga menjadi sebuah persoalan terhadap wali murid, belum lagi persoalan masalah ekonomi mereka yang mengalami penurunan. Penyebabnya yang tak lain adalah masa pengurangan dari tenaga kerja di sebuah kongsi. Akibatnya beban yang dialami oleh orang tua juga bertamah dalam menyiapkan paket kuota internet.

Peserta didik merupakan pokok penting dalam sebuah kesuksesan belajar, karakteristik siswa dapat menentukan keberhasilannya suatu pembelajaran. kepribadian siswa yang tidak baik akan berpengaruh dalam pendidikannya. mereka merasa tidak peduli dengan tugas dan tanggung jawabanya sebagai peserta didik, hal tersebut mengakibatkan pembelajaran menjadi tidak efektif. kebanyakan saat pembelajaran daring anak-anak tidak menggunakan gadgetnya dengan baik justru mereka membuka aplikasi gaming ataupun sosmed dan youtube. Dari hal tersebut dapat disimpulkan bahwa pembelajaran daring berjalan tidak efektif dan terbengkalai. 
Berkaitan dengan hal tersebut orang tua memilki peran penting dalam memberikan nasehat serta pengawasan. Wali kelas, guru bidang studi atau bimbingan konseling harus tetap memaksimalkan dan memberikan pantauan, untuk memastikan kegiatan pembelajaran daring dan tingkah laku anak selama kegiatan belajar dirumah tetap berlangsung dengan baik dan kondusif.

Peran guru bimbingan dan konseling sangat diperlukan dalam upaya membentuk kepribadian peserta didik menjadi lebih baik, apalagi disaat masa pandemi seperti ini peran guru hanya berlangsung pada waktu pembelajaran online saja, berbeda pada saat pembelajaran tatap muka, guru dapat memperhatikan perkembangan pada setiap anak. Program Bimbingan dan konseling terhadap anak usia dini sangat diperlukan dan harus diaplikasikan karena diketahui pada lima tahun pertama anak merupakan masa emas atau disebut degan masa Golden Age, di mana masa ini adalah masa yang tepat untuk proses pembentukan kepribadian pada anak. Proses yang dilakukan di lima tahun pertama terhadap anak akan menentukan bagaimana terbentuknya tingkah laku anak di kemudian hari (Asmidar Parapat, 2020: 9)

\section{Metode Penelitian}

Dalam penulisan artikel ini penulis menggunakan metode studi literatur. Teknik yang digunakan untuk mengumpulkan data melalui analisis dari beberapa sumber rujukan seperti refrensi buku, jurnal, artikel ilmiah yang berhubungan dengan tema yang akan di jadikan sebuah artikel. Dalam melakukan penelitian guna mendapatkan data yang ingin diperoleh ada beberapa langkah yang digunakan seperti membaca, menulis 
poin-poin penting dan mengolah hasil kajian. Penggunaan metode literatur dapat mempermudah dalam melakukan penelitian dan tekniknya pun sesuai dengan keadaan sekarang. kondisi dimana seluruh kegiatan yang ada diluar rumah dibatasi. peneliti mendapatkan berbagai informasi, hanya melalui modal koneksi jaringan internet dan membuka situs web yang dibutuhkan. kegiatan penelitian dapat dilakukan di dalam rumah tanpa harus melakukan pertemuan atau kegiatan observasi di suatu tempat.

\section{Hasil dan Pembahasan}

Bimbingan konseling adalah sebuah pendidikan yang memberikan pelayanan guna untuk mendapatkan tujuan tujuan dari pendidikan tersebut (Dermawan Harefa \& Kaminudin Telaumbanu, 2020: 27) upaya yang dilakukan untuk mendapatkan solusi dalam mengatasi sebuah konflik, kendala dan persoalan sekaligus meningkatkan kesehatan mental.

Faktanya membuktikan bahwa lembaga sekolah secara tidak langsung telah memberikan bimbingan terhadap peserta didiknya, namun belum menyebutnya dengan sebutan bimbingan dan konseling (Ahmad Susanto, 2015: 3)

Usaha kerja keras dan kontribusi dari guru bimbingan konseling bena-benar tercatat didalam permendiknas nomor 111 tahun 2014. Dalam pasal 1 ayat 1 permendikbud menyebutkan "bimbingan dan konseling adalah upaya sistematis, objektif, logis dan berkelanjutan serta terprogram yang dilakukan oleh konselor atau guru bimbingan dan konseling untuk memfasilitasii perkembangan peserta didik/konseli untuk mecapai kemandirian dalam kehidupannya". 
Usaha dalam memecahkan sebuah masalah ialah menjadi tujuan utama dari layanan bimbingan dan konseling. adapun sebuah contoh yang menggambarkan bahwa siswa mampu memecahkan masalahnya sendiri yaitu ia mampu mengambil keputusan dan menentukan mana yang terbaik untuk dirinya. Perbuatan atau tindakan itulah nantinya anak menjadi pribadi yang lebih siap untuk mengambil keputusan atas kehidupan selanjutnya dan berani bertanggung jawab dengan keputusannya.

Guru adalah tenaga pendidik yang menyampaikan ilmunya kepada peserta didik. Mendidik dari yang tidak bisa menjadi bisa dan menemukan potensi pada diri peserta didik. Memberikan nasehat dan mengarahkan peserta didik menjadi lebih baik dari sebelumnya. Guru adalah tenaga pendidik yang memberikan wadah guna sebagai proses transfer ilmu pengetahuan melalui hasil belajar ke peserta didik (Pitalis Mawardi, 2020: 53-54). Sebagai guru atau tenaga pendidik yang professional, tugas utama sebagai guru yaitu mengarahkan, mendidik, melatih, membimbing, mengajar, menilai dan mengevaluasi peserta didik (Pitalis Mawardi, 2020: 54)

Dapat disimpulkan bahwa guru sebagai tenaga pendidik yang professional untuk mengarahkan, mendidik, melatih, membimbing, mengajar, menilai dan mengevaluasi peserta didik dalam sebuah proses transformasi ilmu pengetahuan dari sumber pengetahuan ke peserta didik. Mengetahui lebih dalam terhadap perkembangan pada anak.

Peran guru menjadi sebuah peran yang berkedudukan sebagai orang tua ke dua yang bertanggung jawab menyampaikan beberapa macam ilmu baru yang belum pernah di dapatkan anak selama dirumah. Menjadi wadah bagi anak 
untuk menyalurkan bakat dan potensi yang dimiliki dari setiap peserta didik agar lebih optimal. Sebelumnya disebutkan bahwa peran guru berkedudukan menjadi orang tua ke dua anak, hanya saja jika orang tua memilki peran di lingkup keluarga tetapi guru berada di lingkup sekolah negeri maupun swasta.

Guru adalah tenaga pendidik yang harus digugu dan ditiru. Digugu berarti diyakini atau dipercaya, segala materi yang disampaikan oleh guru jelas sudah dikaji dan dipelajari terlebih dahulu sebagai bahan ajar yang akan disampaikan pada saat akan melakukan pembelajaran di kelas. Maka dari itu pendidik berharap apa yang disampaikan olehnya dapat dipercaya dan diserap dengan baik oleh peserta didik. sedangkan ditiru yaitu dicontoh atau menjadi panutan, disini peran guru sebagai suri teladan bagi muridnya, dari cara berfikir, sikap dan tutur katanya dapat menjadi sebuah contoh tindakan yang dapat ditiru oleh anak.

Dimasa pandemi covid-19 sangat dibutuhkan tenaga pendidik yang professional. Pasalnya kegiatan aktiv pembelajaran disekolah sudah dialihkan menjadi kegiatan belajar di rumah atau belajar online. Segala kegiatan seperti penyampaiaan materi, penugasan dan evaluasi dilakukan secara online. Kelebihan dari belajar online sendiri yaitu dapat melahirkan metode pembelajarann yang efektif terhadap anak. Kegiatan saling berinteraksi antara guru dan murid, peserta didik bebas bertanya jika mereka belum paham dengan materi yang disampaikan oleh gurunya. Dengan demikian guru harus menyiapkan terlebih dahulu mengkaji beberapa materi sehingga pada saat anak meminta untuk menyampaikan suatu hal guru dapat langsung menjelaskan dengan baik dan runtut. 
Peran guru bimbingan dan konseling di masa pandemi memberikan dampak baik sehingga dapat mensuksesan pembelajaran online. Sebagai guru bimbingan dan konseling memiliki upaya mengaplikasikan 3M yaitu, mendengar, memahami, dan merespon (Heni Purwaningsih, 2021: 42) guru bimbingan dan konseling ibarat seperti malaikat tanpa sayap yang berperan penting dalam mengaplikasikan upaya tersebut.

Komunikasi yang berjalan efektif antara guru bimbingan konseling dengan peserta didik sekaligus orang tua akan menjadi sebuah solusi yang efektif di masa pandemi seperti ini. Kemampuan mediasi dari guru BK akan menentukan dan menemukan titik terang terhadap masalah yang dirasakan peseta didik selama pembelajaran daring. Menjadi mediator yang dapat merahasiakan setiap hal yang bersifat pribadi. Kemampuan membaca situasi adalah usaha agartidak terjadinya kesalah pahaman dengan keputusan yang akan diambil dari masalah tersebut.

Karena di masa pandemi ini peran dari guru bimbingan dan konseling memilki peran begitu penting. Memberikan solusi terhadap peserta didinya yang mengalami kesulitan pada saat mengikuti pembelajaran online. Usaha atau langkah yan dapat dilakukan bisa dengan menanyakan bagaimana perkembangan anak selama pembelajaran daring ini melalui platform chat pribadi antara guru dengan orang tua. Dengan demikian guru bimbingan konseling dapat menelaah, memahami dan mengambil keputusan yang terbaik untuk membantu memecahkan masalah anakselama belajar daring.

Beberapa solusi yang dapat diterapkan oleh guru bimbingan dan konseling antara lain sebagai berikut: (1) selalu menjalin komunikasi dan hubungan silaturahmi antara guru 
dengan wali murid menggunakan whatsapp group atau chat pribadi.(2) sesekali melakukan pertemuan pertemuan dengan wali murid sekaligus peserta didik dengan tetap memperhatikan protokol kesehatan. (3) membangun komunikasi yang intens pada setiap guru kelas. (4) melakukan kegiatan home visit di setiap rumah peserta didik yang urgent garis merah benar-benar sangat membutuhkan "rangkulan" dengan jadwal yang sudah ditentukan dan tetap mematuhi protocol kesehatan. memberikan laporan kegiatan ke pihak sekolah. (6) mampu mengevaluasi dan mengupdate diri agar bisa memberikan pelayanan yang lebih kekinian atau tidak membosankan seiring dengan berkembangnya jaman.

\section{Kesimpulan}

Peran guru bimbingan dan konseling dalam pembelajaran daring selama pandemi memilki peran yang sangat penting dan mendukung dalam keberhasilan pembelajarn daring ini. Usaha pendekatan guru yang dilakukan dengan orang tua dan peserta didik. Dapat menyimpulkan dan menemukan titik terang atau solusi dari masalah yang dirasakan anak selama pembelajaran daring. Karena pertemuan antara murid dengan guru hanya melalui teknologi saja. Maka dari itu guru bimbingan dan konseling harus pandai dalam mencari peluang, agar dapat membangun komunikasi yang baik antara guru dengan peserta didik sehingga peserta didik dapat mengikuti pembelajaran jarak jauh dengan nyaman dan bersemangat.

\section{Daftar Pustaka}

Parapat, Asmidar. (2020). Bimbingan Konseling Untuk Anak Usia Dini: Upaya Menumbuhkan Perilaku Prososial. Jawa Barat: Edu Publisher. 
Harefa, Dermawan. Telaumbanu, Kaminudin. (2020) Teori Manajemen Bimbingan \&Konseling Kajian Untuk Mahasiswa Pendidikan Dan Keguruan. Jawa Tengah: PM Publisher.

Susanto, Ahmad. (2015). Bimbingan \& Konseling Di Taman Kanak-Kanak. Jakarta: Prendamedia Group

Mendikbud. (2014). Bimbingan Dan Konseling Pada Pendidikan Dasar Dan Pendidikan Menengah. Indonesia: Kementrian Pendidikan Dan Kebudayaan.

Mawardi, pitalis. (2020). Penelitian tindakan kelas, penelitian tindakan sekolah dan best practice. Jawatimur: CV. Penerbit qiara media.

Purwaningsih, heni. (2021). Peran guru bimbingan dan konseling dalam melayani peserta didik di masa pandemi covid-19. Jurnal inovasi pendidikan dan pengajaran, 1, 42. 